\title{
Plant-Soil-Microbiota Combination for the Removal of Total Petroleum Hydrocarbons (TPH): An In-Field Experiment
}

\section{OPEN ACCESS}

Edited by:

Markus Puschenreiter,

University of Natural Resources and Life Sciences Vienna, Austria

Reviewed by:

Gerhard Soja

Austrian Institute of Technology (AIT)

Austria

Muhammad Afzal,

National Institute for Biotechnology and Genetic Engineering, Pakistan

*Correspondence: Carmine Guarino guarino@unisannio.it

Specialty section: This article was submitted to

Microbiotechnology,

a section of the journal

Frontiers in Microbiology

Received: 26 October 2020 Accepted: 28 December 2020

Published: 26 January 2021

Citation

Zuzolo D, Guarino C, Tartaglia M and Sciarrillo $R$ (2021)

Plant-Soil-Microbiota Combination for the Removal of Total Petroleum Hydrocarbons (TPH): An In-Field

Experiment

Front. Microbiol. 11:621581. doi: 10.3389/fmicb.2020.621581

\section{Daniela Zuzolo, Carmine Guarino*, Maria Tartaglia and Rosaria Sciarrillo \\ Department of Science and Technology, University of Sannio, Benevento, Italy}

The contamination of soil with total petroleum hydrocarbons (TPH) may result in dramatic consequences and needs great attention, as soil rehabilitation would need more effort from a sustainability perspective. However, there is still no known general method since the remediation technology is strictly site-specific. Adaptive biological system dynamics can play a key role in understanding and addressing the potential of situspecific biological combinations for soil pollutants removal. The potential worst-case of TPH contamination reflects soil affected by heavy industrial activities, such as oil refineries. Therefore, the experimental trial was conducted on a 2,000 $\mathrm{m}^{2}$ area from a contaminated site located in northern Italy. We evaluated the remediation potential over time (270 days) assessing (i) the phytoremediation efficiency of two species of Poaceae (Festuca arundinacea Schreb. and Dactylis glomerata L.) and two species of Fabaceae (Medicago sativa L. and Lotus corniculatus L.) and (ii) the role of the indigenous bacteria flora and endo-mycorrhizae consortium addition in plant growth promotion. We also induced resistance to contamination stress in a field experiment. Thirty-three indigenous bacteria selected from the contaminated soils showed marked plant growth promotion. Moreover, functional metagenomics confirmed the metabolic capability of hydrocarbon-degrading microorganisms living in the polluted soil. Our data showed that soil enzymatic activities increased with hydrocarbon degradation rate after 60 days. Both Poaceae and Fabaceae resulted in remarkable remediation potential. Stress markers and antioxidant activity indicated that the selected plant species generally need some time to adapt to TPH stress. In conclusion, our evaluation implied both the rhizosphere effects and functional features of the plant and suggested that plants should (i) have marked tolerance to specific contaminants, (ii) be characterized by an extensive root system, and (iii) be susceptible to arbuscular mycorrhizal fungi (AMF) infection.

Keywords: sustainable remediation, Poaceae, Fabaceae, total petroleum hydrocarbons, mycorrhizae, plants

\section{INTRODUCTION}

The soil pollution produced by total petroleum hydrocarbons (TPH), as aliphatic, aromatic, heterocyclic, and asphaltene/tar hydrocarbons are together termed, constitutes a serious issue worldwide due to eco-toxicity caused by their strong persistence in the environment (Hussain et al., 2019). Most of this pollution has resulted from oil exploration, transport, and refining as 
well as via the lack of waste oil recycling and the disposal of hazardous oil wastes into landfill areas without sufficient management (Khudur et al., 2019; Grifoni et al., 2020). All these anthropic activities have further increased the number of contaminated sites (Koshlaf and Ball, 2017). The consequences of this pollution can be dramatic for soil ecological function since it can lead to a drastic reduction of the soil microbial biomass or the stunted growth of plants (Hussain et al., 2018). Among TPH, long-chain aliphatic hydrocarbons are a group of very recalcitrant compounds that reduce the availability of nutrients in soils, significantly increase water content, and immobilize hydrophobic complexes, thus indirectly affecting the soil's ecological role (Devatha et al., 2019). Soil pollution also affects food security, both by reducing the agricultural production of the soil (as a consequence of plant metabolism impairing and microbial biomass harming) and by making crops unsafe for consumption (Kiamarsi et al., 2020). Hence, detoxification of TPH-contaminated soils has long been a worldwide challenge and has been addressed in various ways in recent years. Therefore, physical-chemical methods have been widely used and are still applied, including excavation, desorption, thermal destruction, soil washing, soil flushing, stabilization, soil vapor extraction, and many others (Vidonish et al., 2016; Ossai et al., 2020). These traditional methods have the advantage of solving the problem in a short amount of time, but costs could be high and the environmental matrices are usually compromised. However, a group of biological technologies capable of degrading hydrocarbons is currently emerging (Guarino and Sciarrillo, 2017; Wang et al., 2019; Ossai et al., 2020). The key benefits are that they act in situ, are low cost, and have a low environmental impact (Palmroth et al., 2006; Gaur et al., 2018). There are different biological approaches to the remediation of TPH contamination, such as bio-pile, biostimulation, bioaugmentation, and phytoremediation, all with a single final objective: the complete mineralization of hydrocarbons (Guarino et al., 2017). Lately, numerous laboratory scale studies have clarified in different ways the potential of these technologies in well-controlled environments but field applications are still not widespread and are considered less attractive than physic-chemical methods (Hoang et al., 2021). Currently, the rising understanding of soil biology and of the natural partnerships existing between the various living organisms occurring in soil (both plants and microbiota) is leading to a growing interest in the application possibilities of adaptive biological dynamics in remediation (Burges et al., 2017; Guarino et al., 2017). However, a greater effort to study these soil dynamics, which primarily affect the rhizosphere, is required to meet the challenge of soil rehabilitation. Generally, the rhizosphere zone has a strong physical and bio-chemical activities network influencing degradation mechanisms of xenobiotics such as hydrocarbons. Degrading bacteria, growth promoters, and ecto- and endophytic fungi are the protagonists (together with plants and, in particular, roots) of interesting degradation co-metabolic processes (Pawlik et al., 2017). In this context, plants play a key role as they shape the conditions for a specific microbial colonization through root exudation (Guyonnet et al., 2018). In addition, root colonizing symbiotic microorganisms, such as arbuscular mycorrhizal fungi (AMF), can play a crucial role in (i) improving the growth stages of the plant, (ii) increasing the biodegradation activity in the rhizosphere, and (iii) enhancing hydrocarbons' uptake at the root level (Rajtor and Piotrowska-Seget, 2016).

The rhizosphere effect is therefore of primary importance in soil reclamation from TPH contamination and is based on mutual benefits brought about by the various organisms through the occurrence of roots exudates, bacterial degrading enzymes, production of growth promoters. and many other molecules which play an important role in regulating the soil bioactivity (Pawlik et al., 2017). It is also necessary to correctly associate this strong potential with the opportunities offered by preparing the land in the best conditions to receive these biological complexes (Liu et al., 2015). In fact, biological systems integrated with suitable agronomic practices could be the keystone for future biological remediation of organic xenobiotic species. Most phytoremediation studies have focused on industrial contaminated soils, which represent the worst-case scenario. In these contexts, a complex approach simultaneously involving agricultural practices and integrated biological systems appears as a suitable strategy to both decrease pollutant concentrations and restore agricultural soil functions over time. However, in situ research of phytoremediation at the metaorganism level (hosting plant and associated microbiome) has long been underestimated and most current studies in the field of hydrocarbons remediation have targeted only one specific group of TPH (i.e., PAHs) (Thijs et al., 2016; Hoang et al., 2021). With this study, we aimed at extending a laboratory-scale experiment (Guarino et al., 2017), in which an evaluation of three bioremediation approaches (natural attenuation, biostimulation, and bioaugmentation) of a TPH-contaminated soil was conducted, to the real-scale. In this in-field experimental study, the remediation of TPHimpacted soils has been evaluated by testing the interaction of four plant species (Festuca arundinacea, Dactilys glomerata, Lotus corniculatus, and Medicago sativa), with indigenous bacteria and inoculated mycorrhizal fungi in the rhizosphere. Our study aimed to (i) examine the TPH rhizodegradation suitability of the experimented plant-microbiome partnership, (ii) determine bacterial diversity and how our treatment would shift it, (iii) assess the potential benefit of synergistic cooperation between the metaorganism in the presence of abiotic stresses (soil pollution), and (iv) propose a method well-suited to field experimentation.

\section{MATERIALS AND METHODS}

\section{Experimental Design}

The in-field experimental trial was conducted on a 2,000$\mathrm{m}^{2}$ area from a decommissioned refinery in the north of Italy (Supplementary Figure S1) characterized by a history of pollution by petroleum hydrocarbons (predominantly diesel). The area was composed of four experimental subzones (named A, B, C, and D) of about $500 \mathrm{~m}^{2}$ each.

The experimental design included the use in all subzones of optimum agronomic practices (landfarming and fertilization) 
and selected plant species (phytoremediation). Mycorrhizae were employed to guarantee plant development promotion as well as beneficial outcomes linked to contamination stress resistance. Landfarming was performed at the beginning of the experiment in all four subzones by the turning of the soil up to a depth of $1.20 \mathrm{~m}$. This operation was carried out three times at regular intervals with the aid of an excavator. The time interval (weekly) between one repetition and another of the intervention was performed to favor better aeration of the substrates, allowing the reconstitution of the microflora in a pervasive manner (United States Environmental Protection Agency [USEPA], 2017).

Fertilization with the mixture of NPK $(105 \mathrm{~kg} / \mathrm{ha}$ of N, $85 \mathrm{~kg} / \mathrm{ha}$ of $\mathrm{P}$, and $85 \mathrm{~kg} / \mathrm{ha}$ of $\mathrm{K}$ ) was carried out with the aforementioned soil turning interventions to ensure a good supply of macronutrients for plants and edaphic microflora.

Irrigation water, which conformed to the Italian legislation (Legislative Decree, 152/2006, data not shown), was supplied using an automatic drip irrigation system (3 liters per square meter). In all subzones, the bioaugmentation process made use of a chosen rhizosphere microorganism mixture $\left(15 \mathrm{~g}\right.$ for $\left.\mathrm{m}^{2}\right)$ composed of fungal endomycorrhizae (Acaulospora colombiana, Rhizophagus clarus, Rhizophagus intraradices, Rhizophagus irregularis Claroideoglomus etunicatum, Funneliformis mosseae, and Funneliformis geosporum) to investigate partnering of mycorrhizal fungi with native bacteria. Festuca arundinacea, Dactilys glomerata, Lotus corniculatus, and Medicago sativa plant species were chosen for soil phytoremediation since the efficiency of Fabaceae and Poaceae in both stimulating the rhizodegradation process and accumulating the hydrocarbons has been recognized by scientific literature (Gao and Zhu, 2004; Hall et al., 2011). Festuca arundinacea seeds $\left(40 \mathrm{~g} / \mathrm{m}^{2}\right)$ were planted in subzone A, Dactilys glomerata $\left(40 \mathrm{~g} / \mathrm{m}^{2}\right)$ in subzone B, Lotus corniculatus $\left(57 \mathrm{~g} / \mathrm{m}^{2}\right)$ in subzone $\mathrm{C}$, and Medicago sativa $\left(57 \mathrm{~g} / \mathrm{m}^{2}\right)$ in subzone D. A neighboring uncontaminated area $(\mathrm{CPH})$ was used as control.

To assess the advancement of the remediation process, soil samples were gathered prior to the experimental trial (BPH) and after the experimental trial (APH) at different periods: days 0 (pretrial-Control, January 2017, $\mathrm{T}_{0}$ ), 90 (March 2017, $\left.\mathrm{T}_{1}\right), 150$ (May 2017, $\mathrm{T}_{2}$ ), 210 (July 2017, $\mathrm{T}_{3}$ ), and 270 (September 2017, $\mathrm{T}_{f}$ ). The soil samples were collected at a $0.40 \mathrm{~cm}$ depth in glass jars, labeled, and stored at $4^{\circ} \mathrm{C}$ for further analysis.

To evaluate the effects of plant stress, in each sub-area, thirtyfive plant samples (separated in roots and leaves) were collected as indicated (black dots) in Supplementary Figure S1. The roots and leaves of each plant were collected, stored in labeled jars at approximately $4^{\circ} \mathrm{C}$, avoiding cross contamination, and transported to the laboratory until analyzed. All samples were analyzed in triplicate.

Metagenomic survey for the analysis of microbial community composition and function of soil included the sampling of (i) contaminated soil prior to the experimental trial (BPH), (ii) after the experimental trial (APH), and (iii) on soil of neighboring uncontaminated area $(\mathrm{CPH})$ used as control. Each sample was composite (as recommended by Vestergaard et al., 2017 and references therein) and represented four randomly selected sampling locations within the indicated areas. Soil samples were immediately placed on ice in a cooler and transported to the laboratory. A half of each sample was frozen in liquid nitrogen and stored at $-80^{\circ} \mathrm{C}$ for subsequent molecular analysis. The remaining half was air-dried and then sieved through a 2-mm-pore-size sieve and finally stored at $4^{\circ} \mathrm{C}$ for further analysis. Along with metagenomics, the physical-chemical assessment of soil samples from control as well as contaminated soils (both before and after the treatment) were carried out (following recommendations of Vestergaard et al., 2017). All samples were analyzed in triplicate.

\section{Analyses}

\section{Isolation of the Autochthonous Soil Bacteria}

A quantity of $1 \mathrm{~g}$ of homogenized and sieved rhizosphere soil of the contaminated chosen area prior $(\mathrm{BPH})$ to the experimental design was suspended in Erlenmeyer flasks (in duplicate) containing $50 \mathrm{ml}$ of a mineral media at $\mathrm{pH} 6.8$ with the addition of $5 \%$ crude oil as a carbon source. Following the method described in Guarino et al. (2017), cultures were transferred in Erlenmeyer flasks containing $250 \mathrm{ml}$ of a mineral media and incubated in an orbital shaker at $28^{\circ} \mathrm{C}$ and $200 \mathrm{rpm}$ for 5 days. Subsequently, in order to isolate the maximum number of strains and avoid the overlooking of slower growing colonies, $100 \mathrm{ml}$ of serial 10-fold dilutions of bacterial cultures were spread on two different solid media: LB and R2A (Sigma-Aldrich, Milan Italy). After 9 days of incubation at $28^{\circ} \mathrm{C}$, a total count of colonies was done. Fifty-one colonies per media had been achieved and preserved and they were randomly selected and maintained as pure cultures per samples.

\section{Molecular Analysis of Autochthonous Bacteria}

The molecular identification of the autochthonous bacteria present in the contaminated soil prior $(\mathrm{BPH})$ and after $(\mathrm{APH})$ the experimental design was obtained following the method reported in Guarino et al. (2019). Two grams of soil were used for the isolation of genomic DNA using the PowerSoil DNA Isolation Kit (MoBio Laboratories Inc., United States), which is effective at removing PCR inhibitors from even the most difficult soil types, according to the producer's protocol. The isolated DNA were quantified by Nanodrop 1000 Spectrophotometer. 16S rRNA gene amplification was performed by using the eubacterialspecific primers (F27a: AGAGTTTGATCCTGGCTCAG; R14 92a: GGTTACCTTGTTACGACTT). Polymerase chain reaction (PCR) were conducted with GoTaq ${ }^{\circledR}$ Polymerase (Promega) according to the manufacturer's instructions. PCR-amplified DNA was sequenced with a BigDye ${ }^{\circledast}$ Terminator v3.1 Cycle Sequencing Kit (Applied Biosystems Inc., United States) adopting an automated DNA sequencer (ABI model 3500 Genetic Analyzer). Nucleotide sequences were edited and assembled with Lasergene version 11.2.1 (DNASTAR ${ }^{\circledR}$ ) and The BLAST search server ${ }^{1}$ was used to search for nucleotide sequence homology of the $16 \mathrm{~S}$ region for bacteria.

\footnotetext{
${ }^{1}$ www.ncbi.nlm.nih.gov/blast/Blast.cgi
} 


\section{In vitro Assessment for Plant Growth Promoting (PGP) Activities}

The isolated bacteria from $\mathrm{BPH}$ soil samples were tested individually for PGP activities to depict bacteria features which might indirectly enhance plant growth. Indolacetic acid (IAA) production, siderophores release, exopolysaccharides (EPSs), and ammonia production were screened following the method of Guarino et al. (2017).

\section{Library Preparation and Sequencing TPH Degrading Genes}

Library preparation and sequencing were performed in soil of the contaminated chosen area prior $(\mathrm{BPH})$ and after $(\mathrm{APH})$ the experimental trial and in soil of a neighboring uncontaminated area $(\mathrm{CPH})$ used as control. Analysis were centered on the genes engaged in hydrocarbon degradation research (Guarino et al., 2020).

The Ovation ${ }^{\circledR}$ Ultralow V2 DNA-Seq kit (Nugen, San Carlos, CA) was adopted for producing libraries. The samples were quantified and quality tested using the Qubit 2.0 Fluorometer (Invitrogen, Carlsbad, CA) and Agilent 2100 Bioanalyzer (Agilent Technologies, Santa Clara, CA). The sequencing run was performed on MiSeq (Illumina, San Diego, CA), sequencing 300 cycles per read. Base calling and demultiplexing were performed on integrated analysis software (Guarino et al., 2019, 2020). The sequenced genes, obtained from Uniprot, are listed below: Alkane-1 monooxygenase (Uniprot code O05895 and P12691), Cytochrome P450 alkane hydroxylase (Uniprot code A9CMS7 and Q2MHE2), Protocatechuate 3,4-dioxygenase (Uniprot code P20372 and Q8NN15), Catechol 1,2-dioxygenase (Uniprot code P07773 and P95607), Catechol 2,3-dioxygenase (Uniprot code Q53034 and P06622), Gentisate 1,2-dioxygenase (Uniprot code Q0SFK9 and Q13ZY3), Homogentisate 1,2-dioxygenase (Uniprot code Q828S5 and B8H072), and Protocatechuate 4,5-dioxygenase (Uniprot code P20371 and P22635). The gene sequences from the isolates were deposited on European Nucleotide Archive (ENA) and are available at www.ebi.ac.uk/ena/submit/sra/\#home.

The short reads were determined by BLAST. All readings with an e-value of less than 0.1 were retained.

\section{Determination of Petroleum Hydrocarbons in Soil and in Plant}

The procedure followed for hydrocarbons' quantification in soil was the one described by Guarino et al. (2017). Sieved soil samples were mixed with sodium sulfate $\left(\mathrm{Na}_{2} \mathrm{SO}_{4}\right)$ to remove excess moisture. Two dichloromethane $\left(\mathrm{CH}_{2} \mathrm{Cl}_{2}\right)$ in series extraction were stirred ( $20 \mathrm{ml}$ of $\mathrm{CH}_{2} \mathrm{Cl}_{2}$ for $5 \mathrm{~g}$ of soil) in a Turbula for $2 \mathrm{~h}$. The clean-up process was performed in silica gel column. Extracts were concentrated under a nitrogen stream at $35^{\circ} \mathrm{C}$ for 50 min using a Zymark TurboVap Evaporator and the residue reconstituted a final volume of $10 \mathrm{ml}$ and was analyzed by GC-MS (7890 A, Agilent, United States) according to the method used for the SimDist analysis (Guarino et al., 2017, 2019). Different hydrocarbon fractions were determined (see Table 1).

For plant analysis, $2 \mathrm{~g}$ of each sample were pulverized with sodium sulfate anhydrous $\left(\mathrm{Na}_{2} \mathrm{SO}_{4}\right)$ by a ceramic mortar and pestle, then extracted and cleaned as described by Guarino et al. (2019) and analyzed by GC-MS (7890 A, Agilent, United States).

\section{Analysis of Enzyme in Soil}

The polyphenol oxidase (PPO), dehydrogenase (DHO), urease (URE), alkaline phosphatase (ALP), and catalase (CAT) activities were assayed in triplicate air-dried samples as described by Liu et al. (2015).

For DHO activity assessment, $0.03 \mathrm{~g}$ of and $0.5 \mathrm{~mL} \mathrm{CaCO} 3$ of $3 \%$ TTC were mixed with a soil sample and incubated at $37^{\circ} \mathrm{C}$ in the dark for $24 \mathrm{~h}$. After adding $5 \mathrm{~mL}$ of methanol, the solution was filtered using a glass funnel capped with absorbent cotton until no red color remained. The samples were diluted to a final volume of $50 \mathrm{~mL}$, adding methanol, and then colorimetrically measured at $485 \mathrm{~nm}$. Control assays (without $\mathrm{CaCO} 3$ and TTC) were simultaneously conducted. For URE activity, a solution of toluene, citrate buffer, and urea were mixed with soil and subsequently incubated at $37^{\circ} \mathrm{C}$ for $24 \mathrm{~h}$. The produced ammonium was determined colorimetrically using the blue Indophenol at $578 \mathrm{~nm}$. A urea-free control was used for each sample. For ALP activity, the soil was mixed with disodium phenylphosphate and borate buffer and incubated at $37^{\circ} \mathrm{C}$ for $2 \mathrm{~h}$. Potassium hexacyanoferrate in alkaline solution was used to extract and oxidize the phenol produced. Measures were done by the 4-aminoantipyrin colorimetric method at $510 \mathrm{~nm}$. Tests without soil and disodiphenyl phosphate were simultaneously assessed as controls. The catalase activity was spectrophotometrically tested in terms of disappearance of the substrate (hydrogen peroxide). (CAT) activity was tested spectrophotometrically and was measured as nmol of $\mathrm{H}_{2} \mathrm{O}_{2}$ $\mathrm{mg}^{-1}$ protein $\mathrm{min}^{-1}$. An enzymatic unit was calculated as the amount of enzyme that catalyzed the consumption of $1 \mu \mathrm{mol}$ of $\mathrm{H}_{2} \mathrm{O}_{2}$ per g of medium per hour (Guarino et al., 2018).

\section{Assessment of Activity of Stress Marker and Antioxidant Enzyme in Leaves}

Fresh leaves $(250 \mathrm{~g})$ of each of the four plants were finely ground in liquid nitrogen into a fine powder and were subsequently centrifuged at $19,000 \mathrm{rpm}$ for $30 \mathrm{~min}$. The activity of stress marker and antioxidant enzymes, such as Glutathione S-Transferase (GST), Phenylalanine Ammonia Lyase (PAL), Proline and Lipid peroxidation (MDA), (Superoxide dismutase (SOD), Catalase (CAT), Ascorbate peroxidase (APX), and Guaiacol peroxidase (GPX), were assessed as described by Guarino et al. $(2018,2020)$.

\section{Staining and Microscopy of Mycorrhizal Fungal Colonization}

Roots of Festuca and Lotus species were sampled 150 days after planting to observe the development of host root colonization.

The fresh fine root segments were fixed in FAA (Formalin: acetic acid: ethanol). The fixed roots were then processed with the staining procedures described by Vohník et al. (2016). Mycorrhizal colonization was estimated after clarifying ( $10 \%$ $\mathrm{KOH})$ at $121^{\circ} \mathrm{C}$ for $15 \mathrm{~min}$, acidifying $(\% \mathrm{HCl})$ for $20 \mathrm{~s}$, and staining in $0.05 \%$ Trypan blue solution in lactoglycerol (lactic acid/glycerol/deionized water in a mixing ratio of 1:1:3) for 
TABLE 1 | Concentrations of different hydrocarbons fractions in A, B, C, and D subzone's soils over time and removal rate of hydrocarbons fractions (TO, T1, T2, T3, TF).

\begin{tabular}{|c|c|c|c|c|c|c|c|}
\hline Subzone & Parameter $(\mathbf{m g} / \mathbf{k g})$ & $T_{0}$ (0 Days) & $\mathrm{T}_{1}$ (90 Days) & $\mathrm{T}_{2}$ (150 Days) & $T_{3}$ (210 Days) & $\mathrm{T}_{F}$ (270 Days) & $\begin{array}{l}\text { Removal rate }(\%) \text { during the } \\
\text { different time of treatment }\end{array}$ \\
\hline \multirow[t]{5}{*}{ A } & $\mathrm{C}_{10-12}$ & $34^{a} \pm 5$ & $16^{b} \pm 5$ & $10^{c} \pm 2$ & $5^{\mathrm{cd}} \pm 2$ & $3^{d} \pm 1$ & 91 \\
\hline & $\mathrm{C}_{16}-\mathrm{C}_{21}$ & $1292^{a} \pm 121$ & $647^{b} \pm 12$ & $299^{c} \pm 25$ & $151^{\mathrm{cd}} \pm 45$ & $73^{d} \pm 12$ & 94 \\
\hline & $\mathrm{C}_{21}-\mathrm{C}_{40}$ & $2240^{\mathrm{a}} \pm 156$ & $1424^{b} \pm 123$ & $1463^{b} \pm 101$ & $885^{\mathrm{C}} \pm 85$ & $383^{d} \pm 103$ & 82 \\
\hline & Total $\mathrm{C}_{10-40}$ & $3720^{\mathrm{a}} \pm 164$ & $2163^{b} \pm 258$ & $1816^{\mathrm{b}} \pm 124$ & $1070^{C} \pm 99$ & $474^{d} \pm 111$ & 87 \\
\hline & $\mathrm{HC}>12$ & $3757^{a} \pm 147$ & $2220^{b} \pm 125$ & $1777^{b} \pm 141$ & $1136^{C} \pm 124$ & $489^{d} \pm 103$ & 86 \\
\hline \multirow[t]{4}{*}{$B$} & $C_{10-12}$ & $37^{a} \pm 8$ & $18^{b} \pm 5$ & $11^{\mathrm{C}} \pm 3$ & $6^{\mathrm{cd}} \pm 1$ & $3^{d} \pm 1$ & 91 \\
\hline & $\mathrm{C}_{12-16}$ & $156^{a} \pm 13$ & $79^{b} \pm 8$ & $38^{c} \pm 10$ & $20^{\text {cd }} \pm 5$ & $12^{d} \pm 3$ & 92 \\
\hline & $\mathrm{C}_{16}-\mathrm{C}_{21}$ & $1102^{\mathrm{a}} \pm 105$ & $570^{\mathrm{b}} \pm 15$ & $289^{c} \pm 28$ & $151^{\mathrm{cd}} \pm 14$ & $77^{d} \pm 12$ & 93 \\
\hline & $\mathrm{C}_{21}-\mathrm{C}_{40}$ & $2335^{a} \pm 153$ & $1576^{b} \pm 132$ & $1577^{\mathrm{b}} \pm 56$ & $965^{c} \pm 54$ & $334^{d} \pm 101$ & 85 \\
\hline \multirow[t]{8}{*}{ C } & $C_{10-12}$ & $31^{a} \pm 5$ & $17^{\mathrm{b}} \pm 5$ & $g^{c} \pm 1$ & $5^{\mathrm{cd}} \pm 1$ & $3^{d} \pm 1$ & 90 \\
\hline & $\mathrm{C}_{12-16}$ & $193^{a} \pm 10$ & $98^{b} \pm 10$ & $50^{c} \pm 5$ & $25^{\mathrm{cd}} \pm 10$ & $13^{d} \pm 4$ & 93 \\
\hline & $\mathrm{C}_{16}-\mathrm{C}_{21}$ & $1037^{a} \pm 123$ & $522^{\mathrm{b}} \pm 37$ & $266^{c} \pm 12$ & $138^{\mathrm{cd}} \pm 35$ & $70^{d} \pm 10$ & 93 \\
\hline & $\mathrm{C}_{21}-\mathrm{C}_{40}$ & $2109^{a} \pm 140$ & $1371^{b} \pm 58$ & $1299^{b} \pm 103$ & $667^{c} \pm 45$ & $279^{d} \pm 23$ & 96 \\
\hline & Total $C_{10-40}$ & $3370^{a} \pm 138$ & $2009^{b} \pm 82$ & $1624^{b} \pm 104$ & $836^{c} \pm 102$ & $365^{d} \pm 25$ & 89 \\
\hline & $\mathrm{TPH}$ & $3408^{a} \pm 124$ & $2034^{b} \pm 92$ & $1647^{b} \pm 111$ & $846^{c} \pm 113$ & $369^{d} \pm 28$ & 89 \\
\hline & $\mathrm{HC}<12$ & $31^{a} \pm 10$ & $14^{b} \pm 5$ & $4^{c} \pm 1$ & $2^{c} \pm 1$ & $2^{\mathrm{C}} \pm 1$ & 93 \\
\hline & $\mathrm{HC}>12$ & $3378^{a} \pm 123$ & $2021^{b} \pm 104$ & $1644^{b} \pm 95$ & $845^{c} \pm 65$ & $369^{d} \pm 36$ & 89 \\
\hline \multirow[t]{2}{*}{ D } & $\mathrm{C}_{10-12}$ & $28^{a} \pm 5$ & $14^{b} \pm 2$ & $4^{c} \pm 2$ & $2^{\mathrm{cd}} \pm 0.05$ & $1^{d} \pm 0.03$ & 96 \\
\hline & $C_{12-16}$ & $183^{a} \pm 11$ & $95^{b} \pm 10$ & $48^{c} \pm 5$ & $25^{\mathrm{cd}} \pm 5$ & $13^{d} \pm 4$ & 92 \\
\hline
\end{tabular}

Mean values $(n=3) \pm S E$ followed by non-identical lower-case letters (a-e) indicate significant difference $(p<0.05)$ among the different times (Duncan's test).

5 min. The excess stain was removed in clear lactoglycerol at room temperature and roots were subsequently placed on glass slides for microscopic observation. The percentage of intracellular hyphal colonization was assessed using a Nikon Eclipse E600 microscope.

\section{Statistical Data Analysis}

The data presented are the mean \pm SE. The data were statistically analyzed by means comparison by the parametric ANOVA (considering conservative F statistics for determining significance) and non-parametric Kruskal-Wallis tests (with Bonferroni correction of the p-value). Duncan's post-hoc test was used for pairwise comparison. Results of both parametric and non-parametric analyses were quite comparable. Although non-parametric analyses are beneficial because they are free of the assumptions of parametric ones, they are generally considered less robust than parametric analyses (Field, 2009; DePoy and Gitlin, 2016). Hence, only ANOVA analyses results were considered in our study. A one-way ANOVA was adopted to assess whether the hydrocarbons accumulation/translocation (concentration in roots and leaves, respectively) differed among plant species. The two-way ANOVA analyses were performed to test whether the experimental time, plant species, and the interaction between these two factors have an effect on (i) hydrocarbons contamination levels in the pot experiment and (ii) plant antioxidant response (enzymatic activity). A significant difference was considered at the level of $p<0.05$.

\section{RESULTS}

\section{Determination of the Physic-Chemical Parameters}

The parameters of control soil $(\mathrm{CPH})$ and contaminated soils before $(\mathrm{BPH})$ and after treatment $(\mathrm{APH})$ sites are shown 
in Supplementary Table S1. It has been observed that the application of NPK fertilizers increased soil nutrients (BPH and $\mathrm{APH}$ ) with respect to the control soil. In addition, soil with TPH contamination without treatment (BPH) is characterized by a higher nitrogen (1.5 times) and potassium (1-3 times) content as compared to soil after the experimental trial (APH). The lower $\mathrm{N}$ levels in APH may be imputed to the uptake of $\mathrm{N}$ and $\mathrm{P}$ by vegetation, and therefore to their storage function, which could have been enhanced by the AMF activity. In fact, after the treatment, these parameters tend to be very close to those of the control soil. Total organic carbon (TOC) was 1.10 and $0.79 \%$ for polluted soil without treatment and uncontaminated soil, respectively. After the treatment, TOC was $0.98 \%$, which is very similar to control sample value.

\section{Bacterial Diversity and Functional Analyses of TPH Degrading Genes}

The three DNA libraries (contaminated soil before and after treatment) were performed. GAIA and KRAKEN analyzed the taxonomic sequenced reads. The reads were assigned to the superkingdom Bacteria for contaminated soil (before and after treatment) ( 95.8\%). The dominant phyla were Proteobacteria (60\%) followed by Firmicutes (18.2\%), Actinobacteria (6.2\%), Bacteroidetes (6.6\%), and Acidobacteria (0.5\%). In hydrocarbon-contaminated soil, there is an enhancement of Proteobacteria, frequently dominated by Gammaproteobacteria, which positively reacts to the influx of hydrocarbon substrates and supplemental nutrients supply (Greer et al., 2010; Bell et al., 2014). The presence of Alphaproteobacteria was also noticeable (about 30\%) with the Sphingomonadales, Rhospirales, and Rhizobiales orders. Among the Betaproteobacteria, the Burkholderiales order was predominant. Within the Firmicutes, the Bacillales order with the families Bacillaceae and Penibacillaceae were prevailing; among the Actinobacteria, Microccaceae (gen Arthrobacter) and Nocardiaceae were the uppermost families. Lower percentages of Bacteroidetes and Acidobacteria were also present. Furthermore, in the context of bacterial diversity, Chloroflexi, Chlorobi, and Nitospirae were present with modest percentages (1$1.3 \%)$. In any case, the soil showed interesting amounts of Apicoplexa (protozoa), Chlorophyta (algae), and fungi belonging to Ascomycota and Basidiomycota.

After the treatment (APH), the Proteobacteria quota increased by about $15 \%$ with an increase in Rhizobiales and this was attributable to the nitrogen-fixing species introduced (Medicago and Lotus), but Pseudomonadales and Burkholderiales also consistently grew. Firmicutes with the Bacillaceae family also showed a significant increase. However, the panorama of microbial diversity changed in relation to the presence of Glomeromycota (microbial consortium introduced) as proof of the mycorrhization success. The presence of Basidiomycota and Ascomycota, despite being low, was constant. The microscopic analysis (Figure 1) of both Festuca and Lotus roots clearly demonstrate root colonization, highlighting the presence of typical VAM structures. Figures 1A,B depict Festuca root fragments and show intraradical vesicles (v) and hyphae (h). In Figure 1B, an intracellular microsclerotia structure (m) with rounded hyphae cells is also visible. On the other hand, Figures 1C-F represent Lotus roots showing an effective nodulation, with nodules heavily infiltrated by Rhizobium bacteria. Nodulation evidence demonstrates that our treatment is suitable for nodule formation and contains Lotuscompatible rhizobia.

In the context of bacterial diversity, the genera most represented after the treatment were Pseudomonas, Comamonas, Achromobacter, Acetobacter, Sphingobium, Burkholderia, Bacillus, Rhizobium, and Bradyrhizobium, most of which have been recognized as mycorrhizal helper bacteria or root growth stimulators (Poole et al., 2001; Johannsson et al., 2004; Labbé et al., 2011). Obviously, the increase in the fungal component with the Glomeromycota has strongly changed the rhizosphere dynamics. Our data also demonstrate that the uniformity of soil bacterial community rises as TPH removal increases, in accordance with previous studies (e.g., Siles and Margesin, 2018). This may be the outcome of a well-established bacterial community in the studied soil, adapted to the existing conditions and to the use of the contaminants present in the system as carbon and energy sources (Serrano et al., 2008). In addition, TPH contents guide the shifts in bacterial community composition.

In soil there is a multitude of enzymes that are important in the conversion of organic substances and energy (Gu et al., 2009). The main class of oxidoreductases are dehydrogenases that are the indicators of global soil microbiological activity (Kaczyñska et al., 2015). Our data demonstrated a high gene abundance of several oxidoreductases involved in hydrocarbon removal, suggesting the degradation prospect of native soil microorganisms. As matter of fact, our data (Figure 2) demonstrate that in hydrocarbon-contaminated soils, both in APH (contaminated soil after treatment) and BPH (contaminated soil before treatment) the degrading genes are far superior than those of $\mathrm{CPH}$ (control soil). The APH and BPH soils show abundant amounts of the genes encoding for dehydrogenases, such as naphthalene 1,2dioxygenase, extradiol dioxygenase, benzoate 1,2 dioxygenase, protocatechuate 4,5-dioxygenase (alpha and beta chain), and 1,2-dihydroxynaphthalene dioxygenase (Figure 2). Therefore, in accordance with our data, it is possible to hypothesize a particular sensitivity of dehydrogenases to the existence of petroleumrelated compounds in the soil (as also observed by Kaczyñska et al., 2015). This provides evidence that dehydrogenases have the ability to accelerate the microbiological degradation of such contaminants. We observe the substantial increase in enzymatic activity in correlation with the hydrocarbons' degradation. These results are in agreement with the current literature, which has shown a strong correlation between the presence of TPH in soils and the abundance of degrading genes produced both by the native micro-channels present and by those introduced as inoculum. In the latter case, co-metabolism factors are triggered, affecting the increase in the enzymatic fitness. In fact, our treatment improved the abundance of hydrocarbon-degrading genes, proving to be suitable for an enhanced soil remediation. 

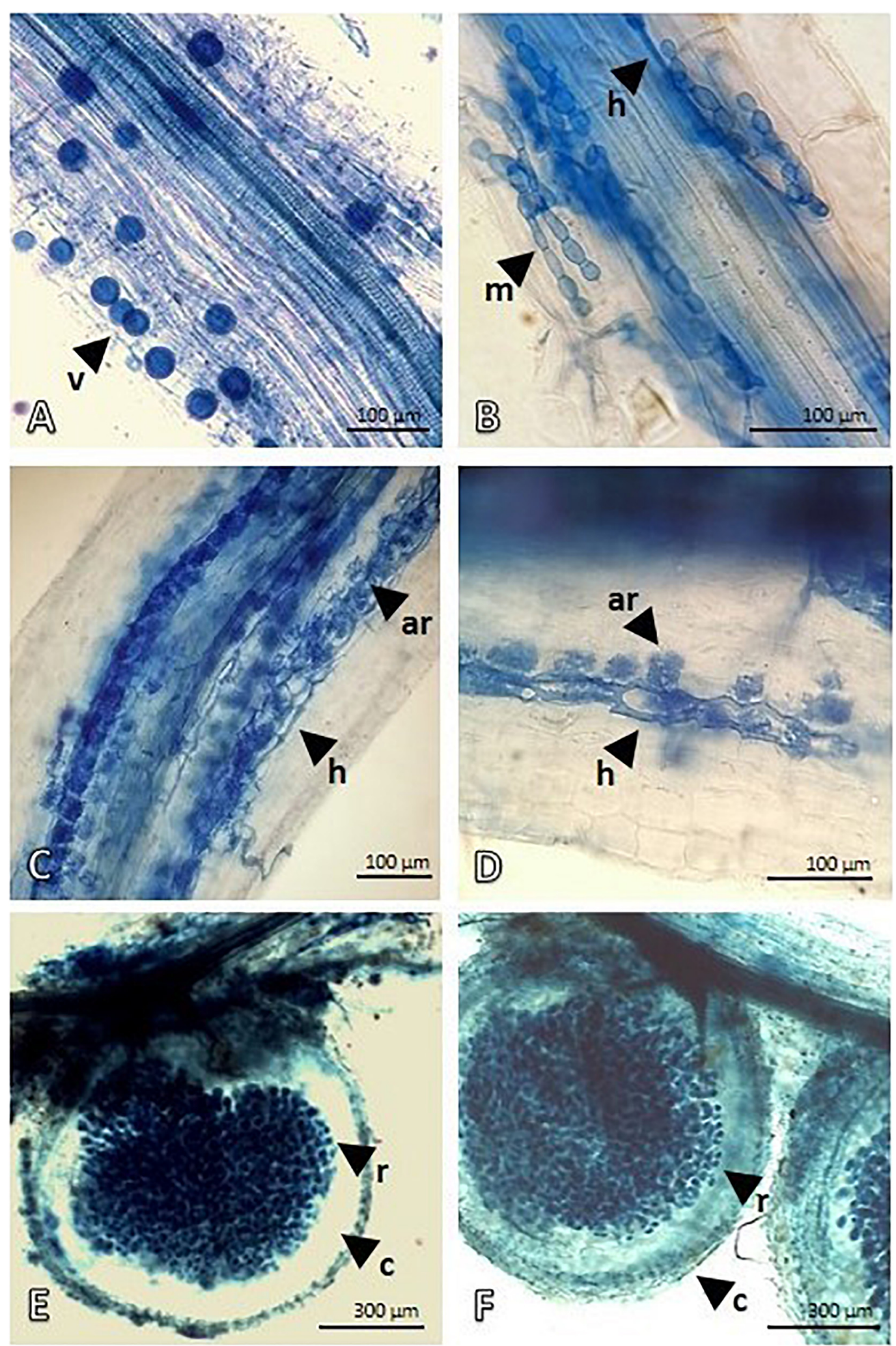

FIGURE 1 | Mycorrhization of Lotus and Festuca roots and Rhizobium nodules of Lotus roots detected by Trypan Blue staining and light microscopy. (A,B) show the mycorrhize colonization in Festuca roots. Intraradical vesicles (v) and hyphae (h) developing intracellular microsclerotia structure (m), with rounded hyphae cell, are visible in root fragments. (C,D) show Intraradical hyphae (h) depicting an advanced arbuscule colonization in Lotus roots. (E,F) display Lotus root nodules. Outer, lighter stained, cortex of nodule is well-distinguished from the symbiotic region that is heavily infiltrated by Rhizobium bacteria. 


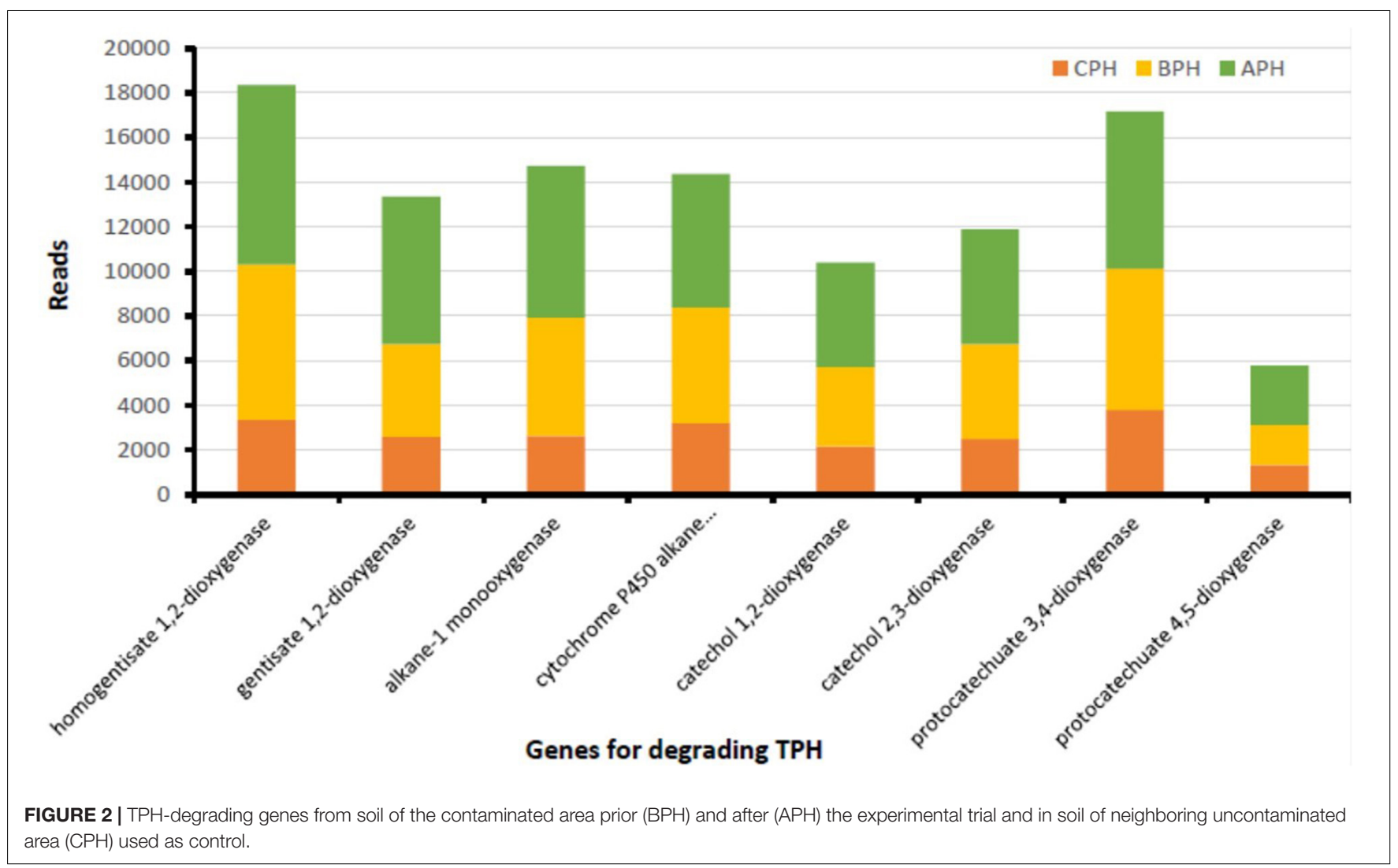

\section{Determination of the Isolated Hydrocarbon Degrader's Bacteria in Soil}

The in vitro tests carried out to show their plant growth promotion potentiality revealed that $72 \%$ of the isolated strains are able to produce the phythormones IAA, whereas $66 \%$ lead to EPS's production. In addition, the $78 \%$ of isolates exhibit production of siderophores and more than half of them (about 60\%) are able to release Ammonia (Supplementary Table S2).

\section{Degradation of Petroleum Hydrocarbons in Soil}

Table 1 shows the TPH levels and their fractions in the four subzones. In all the experiments, the concentrations of hydrocarbon with $\mathrm{C}<12$ are essentially insignificant (Table 1). Concentrations of hydrocarbon with $\mathrm{C}>12$ show removal percentages very close to total petroleum hydrocarbon. Statistical analyses revealed that time plays a key role in hydrocarbon concentration levels in soil. The results suggested that grasses' (Fes and Dac) and legumes' (Lot and Med) growth increases the removal of TPH from polluted soils. Indeed, cultivated soils had significantly lower hydrocarbons after 90 days with a final TPH removal rate ranging from 87 to $89 \%$.

\section{Soil Enzyme Activity}

Supplementary Figure S2 shows the variation in PPO, DHO, ALP, URE, and CAT activities in rhizosphere soil in relation to days of growth. Rhizosphere soil PPO activity generally rose over time in all subzones with a significant $(p<0.05)$ increase after 90 days $\left(\mathrm{T}_{1}\right)$. It can be associated with the progressive reduction of TPH concentrations in soil. In fact, the correlation between PPO activities of rhizosphere soil (Supplementary Figure S2) and degradation of TPH in soil (Table 1) indicates that soil adapted to TPH pollution by developing polyphenol oxidase after plants growth.

The soil DHO activity did not vary in the different plant species but was affected by TPH degradation amount over diverse growth periods. The DHO activity showed a significant increase after 150 days $\left(\mathrm{T}_{1}\right)$ and continued to rise until the end of the experiment (Supplementary Figure S2).

The soil alkaline phosphatase (ALP) activity significantly enhanced $(p<0.05)$ after $90\left(\mathrm{~T}_{1}\right)$ and $150 \quad\left(\mathrm{~T}_{2}\right)$ days (Supplementary Figure S2).

The urease activity in rhizosphere soil was largely enhanced after $\mathrm{T}_{1}$ (90 days) and $\mathrm{T}_{2}$ (150 days). These results denote that the presence of hydrocarbons in the soil did not discourage URE activity at the initial stage of plant growth, suggesting the existence of a stabilized portion of urease that is extremely resistant to pollutants. Results also show that soil URE activity of the four species continuously rose over time (Supplementary Figure S2). The rise of URE activity is helpful for plants because it supports the hydrolysis of nitrogen and carbon in contaminated soil, facilitating the degradation hydrocarbons in soil.

The dependence of catalase (CAT) soil activity over time showed an increasing trend. Statistical differences were observed after 90 and 150 days. CAT is another intracellular enzyme 
developed by all aerobic bacteria and most facultative anaerobes, and is an indicator of the soil community activity and soil fertility (Woliñska et al., 2016).

We share the opinion that increased enzymatic activity of soil is a footprint of the highly consolidated associations between plants and microorganisms, both symbiotic and plant growthpromoting rhizobacteria (Gianfreda, 2015). This interaction also improves the transformation and/or degradation of polluting compounds. Therefore, our data shows that soil enzymatic activities were more substantial after 90 days $\left(\mathrm{T}_{1}\right)$ and enhanced at the end of the experiment (270 days), a tendency that is correlated to the amount of TPH degradation rate in soil.

\section{Petroleum Hydrocarbons in Plants}

The concentrations of total petroleum hydrocarbons (TPH) found in plant samples (roots and leaves) are shown in Figure 3. Our results indicated that Festuca arundinacea, Dactilys glomerata, Lotus corniculatus, and Medicago sativa have good remediation potential in TPH-polluted soils. Statistical analyses revealed that a significant difference between Festuca and the other plant species was found in terms of overall hydrocarbons root concentrations. In fact, TPH concentrations in Festuca samples ranged between 13 and $38 \mathrm{mg} / \mathrm{kg}$ in roots and 1.5$10 \mathrm{mg} / \mathrm{kg}$ in leaves from 90 days $\left(\mathrm{T}_{1}\right)$ to 270 days $\left(\mathrm{T}_{f}\right)$. In Dactilys, TPH concentrations in samples ranged between 14 and $30 \mathrm{mg} / \mathrm{kg}$ in roots and $5-11 \mathrm{mg} / \mathrm{kg}$ in leaves from 90 days to 270 days.

In Lotus, TPH concentrations were between 15 and $31 \mathrm{mg} / \mathrm{kg}$ in roots and $3-9 \mathrm{mg} / \mathrm{kg}$ in leaves from 90 days to 270 days. In Medicago, TPH concentrations in samples ranged between 13 and $31 \mathrm{mg} / \mathrm{kg}$ in roots and $3-9 \mathrm{mg} / \mathrm{kg}$ in leaves from 90 days to 270 days. These results showed that TPH concentrations in plant samples were higher in roots and lower in leaves.

Comparing the TPH content in both analyzed parts (roots and leaves) of the plant, a higher accumulation of $\mathrm{TPH}$ through the roots occurs. These results indicate that the uptake of petroleum hydrocarbons in roots is enhanced through a rhizodegradation mechanism. In rhizodegradation, organic pollutants are degraded in soil through the bioactivity of the rhizosphere, which derives from the production and exudation of enzymes and proteins by plants or soil microorganisms such as bacteria or fungi (Guarino et al., 2020). The lower levels of TPH in leaves may be related to the hydrocarbons phytotransformation or phytodegradation occurring within the plant itself.

\section{Stress Marker and Antioxidant Enzyme Activity in Plants}

Reactive oxygen species (ROS) are generated in several redox reactions in plants since they play the role of signaling molecules involved in various phases (e.g., growth and development). However, environmental stress, such as pollution of soil in which plants grow, can favor the intracellular levels of ROS due to the alteration of the equilibrium between ROS production and scavenging (Hayat et al., 2012). To avoid cellular damage caused by oxidative stress, plants accumulate osmolytes (e.g., proline, glycine-betaine, polyamines, and sugars) to safeguard the cellular machinery and inhibit the production of harmful ROS. In our experiment, antioxidant enzymes and stress marker activities were determined in leaves of the four plant species (Supplementary Figure S3) to evaluate the defense strategy set under abiotic stress (such as TPH pollution) to regulate ROS toxic levels and avoid oxidative damage. Statistical analyses highlight that the variations in the activities of all the evaluated enzymes were related to the progression of the experimental time. The activity of SOD in all studied species decreased significantly $(p<0.05)$ over experimental time. The enhanced SOD activity in leaves at T1 (90 days) could be related to a higher TPH exposure, even in the presence of microorganisms able to promote plant growth. CAT activity in the leaves of both Poaceae and Fabaceae showed decreasing patterns similar to SOD activity, lowering over time. GPX and APX pattern unveiled that a significant reduction is observed over longer periods of time.

In order to estimate the level of oxidative stress, the malandialdehyde content (MDA), Glutathione S-Transferase (GST), Phenylalanine Ammonia Lyase (PAL), and Proline content were determined, and our results indicate a decreasing pattern over the experimental time. MDA is a widely used marker of oxidative lipid damage caused by enhanced levels of ROS under stress. After 270 days, MDA level decreased in leaf samples of all the investigated plant species. These findings are in accordance with other research highlighting that MDA levels in leaves increased with increasing crude oil concentration in soil and decreased with exposure time (Shukry et al., 2013; Guarino et al., 2020). The decreasing MDA trend over time may indicate that, under hydrocarbons' degradation, repairing mechanisms start to keep pace with oxidative damage. As regards proline, at an earlier time we observed higher contents, which decreased as TPH concentration diminished in the soil. Our data may suggest that the investigated plants suffer stress at early stages due to the high levels of soil contamination and thereafter respond by enhancing their tolerance and inhibiting the production of harmful ROS.

\section{DISCUSSION}

For effective phytoremediation, it is mandatory to gather key information from field experiments. A theoretical approach based only on laboratory data may not be sufficient. Unfortunately, the geo-environmental conditions are sitespecific, and therefore bioremediation models must be contextualized to the actual location where reclamation will take place. Using integrated remediation systems is very useful, especially when pollutants are hydrocarbons. In fact, the choice to use landfarming first and then biostimulation is based on two main objectives: (1) to obtain a quota of degradation through thermal (solar) and oxygenation processes and (2) to create an environment more conducive to the microbial growth of the potential autochthonous microflora present on site. Also. the identification of particular microorganisms in soils to be reclaimed that have both a degradation activity and/or act as Plant Growth-Promoting Rhizobacteria (PGPR) 


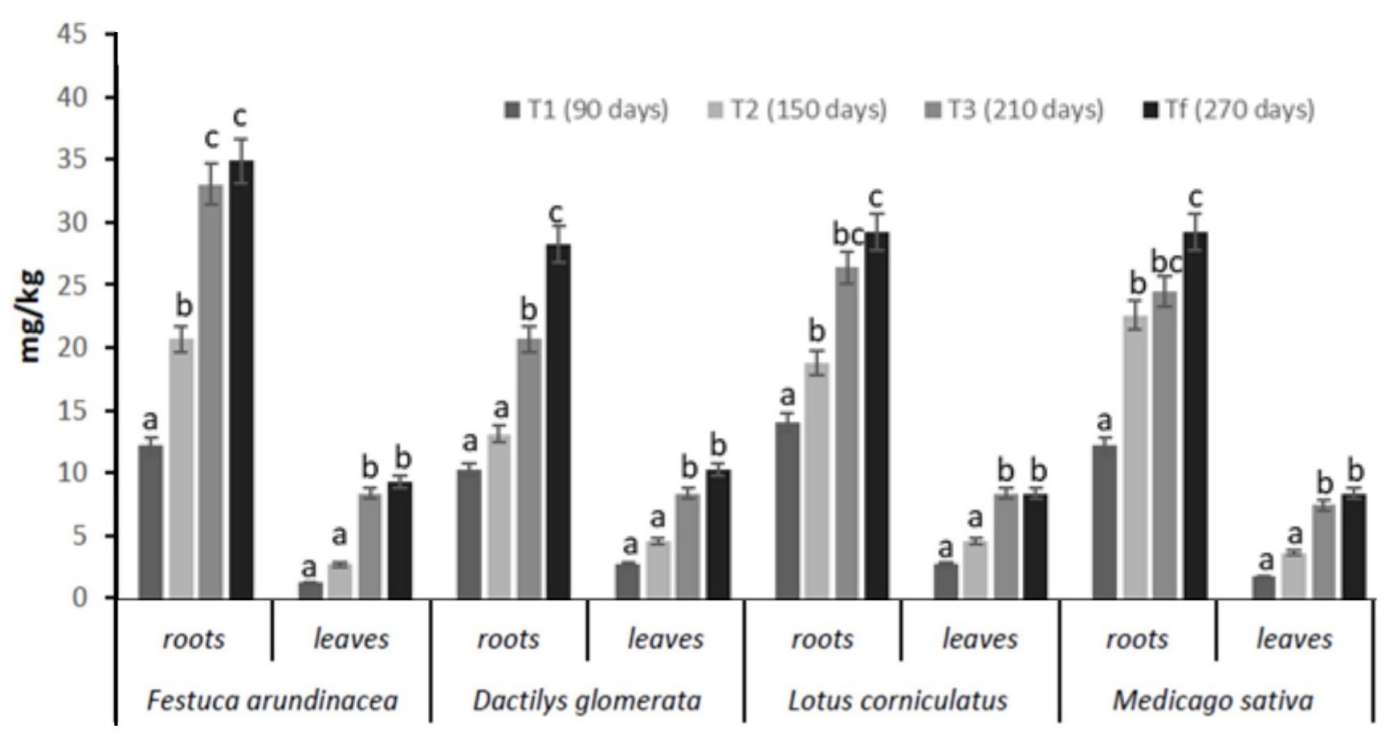

FIGURE 3 | Levels of TPH in roots and leaves of Festuca arundinacea, Dactylis glomerata, Medicago sativa, and Lotus corniculatus after 90 ( $\left.T_{1}\right)$, 150 ( $\left.T_{2}\right), 210$ ( $\left.T_{3}\right)$, and $270\left(T_{f}\right)$. Means \pm SE with different letter indicate significant difference according to Duncan's test $(p<0.05)$.

is essential for the success of the intervention. In our case, 33 bacteria were isolated, showing different and marked activities such as production of IAA (Indole Acetic Acid), siderophores capacity, or production of EPSs (Extracellular Polymeric Substances).

The significance of nutrients in hydrocarbon-contaminated soils has long been recognized since they support microbial activities. Macronutrients, such as N-P-K, are also essential for the production of amino acids and the transport of energy (such as adenosine triphosphate, which is needed for symbiotic $\mathrm{N}$-fixation). In fact, many authors have described that soil fertilization with NPK fertilizer results in enhanced TPH rhizoremediation up to 65\% (Vaajasaari et al., 2006). Hence, nutrient external supplements to enhance the development of microbial flora and improve plant growth has been considered to promote the hydrocarbons' removal. The plant species chosen in this study for hydrocarbons' phytoremediation are characterized by suitable features, such as (i) a remarkable tolerance to specific contaminants, (ii) extensive root systems, and (iii) a marked susceptibility to AMF (Arbuscular Mycorrhizal Fungi) infections. In particular, Poaceae have a fibrous root system (with a high specific surface) and are able to actively explore deeper soil layers (up to $100 \mathrm{~cm}$ ), which improves the contact between contaminants and degrading microbes (Cougnon et al., 2017). In addition, the chosen Poaceae can emit high quantities of soluble organic substances and secondary metabolites in the rhizosphere, which are directly and indirectly involved in the degradation of pollutants. The root infection with mycorrhizal fungi was also a goal of our experiment since it is well-recognized that mycorrhization can (i) enhance the hydrocarbon degradation in soils, (ii) improve nitrogen fixation (especially for Fabaceae), which is of particular interest for its ecological and agronomic implications
(Hernández-Ortega et al., 2012), and (iii) alleviate hydrocarbon toxicity on plants.

Many authors have highlighted the role of Fabaceae in phytoremediation as these taxa offer wide perspectives of adaptations to soils contaminated by oil (Hall et al., 2011). The symbiotic association between rhizobia and Fabaceae may result in $\mathrm{N}$ fixation and thus in soil fertility and productivity improvement. Therefore, the plant species chosen in this field experiment have all the characteristics of suitability for soil function rehabilitation. Medicago sativa has an extensive and efficient root system both in terms of production of compounds (exudates) very useful for the native microbial flora and for the ability to develop symbiosis with nitrogenfixing bacteria. Lotus corniculatus is among the most frequent species in disturbed areas of the Mediterranean basin, a rustic and N-fixing species. Both Festuca and Dactylis represent pioneer plants of nutrient-poor soils and polluted soils and have been used in various field and laboratory experiments due to their efficiency in TPH degradation. In our infield experiment, Festuca arundinacea (Poaceaer family) with inoculation of endophytic fungi showed more root biomass and enhanced hydrocarbons' root accumulation and degradation.

Because of hydrocarbon hydrophobicity, there could have been problems for plants in the assimilation of water and nutrients. However, many studies have shown that these issues can be overcome by introducing mycorrhizae. Furthermore, the beneficial effects of mycorrhizae on the growing process of plants exposed to abiotic stress is reflected in the ability to obtain a new homeostatic equilibrium with the regulation of stress markers. The microorganism-plant associations improve the transformation and/or degradation of polluting compounds, ultimately resulting in their removal and thereby 


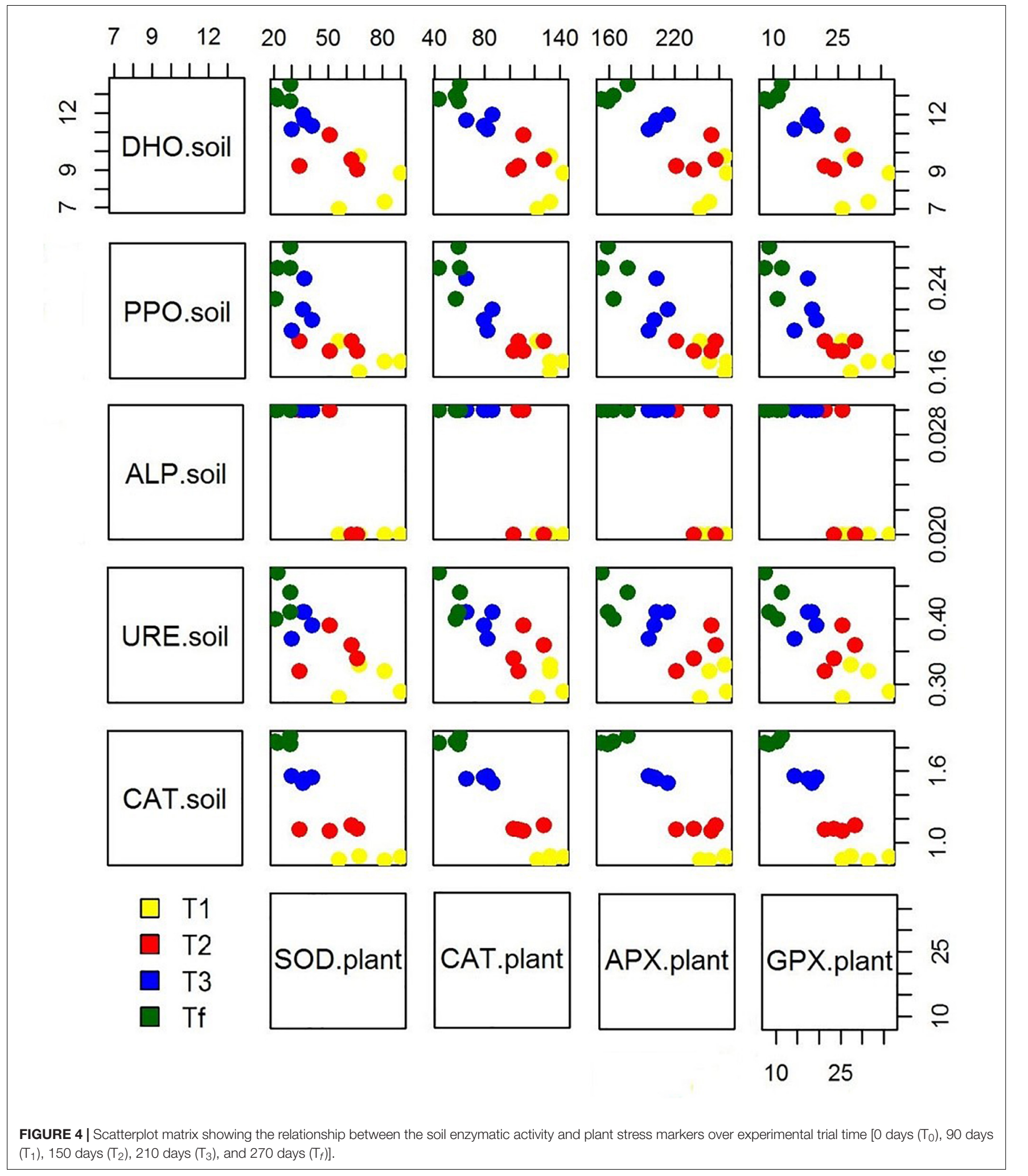

in lower level of abiotic stress for plants. As a matter of fact, our data showed that as soil enzymatic activity grows over time, a reduced antioxidant response in plants can be observed
(Figure 4). Our observations are in accordance with other studies (e.g., Balseiro-Romero et al., 2017; Rusin et al., 2018) which observed that plant-microbial interactions could decrease 
antioxidant enzymes activity in plant growing in dieselcontaminated soil. The significant reduction of enzyme activities in plants may reveal an enhanced abiotic stress tolerance, which is directly related to the growing dissipation of hydrocarbons and indirectly linked to the rhizosphere effect. Moreover, the degradation of hydrophobic petroleum compounds may have improved the water holding capacity in soils (Hussain et al., 2019), resulting in increased available water content for plants. In addition, the co-activity of plants and associated microorganisms enhances nutrient availability in soil (Gkorezis et al., 2016), with a direct effect on the biofortification of plants.

The degradation of hydrocarbons in our site may be mainly based on AMF-mediated rhizodegradation. The mycelium produced by mycorrhizae fungus increases the rhizosphere surface allowing a greater root exploration, forming the hyphosphere which represents a favorable habitat for soil microorganism activity and proliferation (Andrade et al., 1997).

In rhizodegradation, both the enzymes of the microbiota and those produced by the roots contribute to the progress of hydrocarbon degradation. Monitoring the enzymatic activities at the rhizosphere level is essential to understand the evolution of the degradation process and the success of the experiment. In the structure of the hyphosphere, the high activity of oxidoreductase, such as dehydrogenase, catalase, polyphenol oxidase, peroxidase, dioxygenase and superoxide dismutase, was observed. In our case, the enzymatic activities found in rhizosphere soil (PPO, DHO, ALP, and URE) increase proportionally with the development of rhizosphere biomass and the degree of infection of AMF. In fact, the more this symbiotic relationship is consistent, the more it will increase rhizosphere biomass and the consequent enzymatic activities.

The integrated biological systems of phytoremediation exploit the synergistic effect of the plant-bacteria-mycorrhizae relationship. In this context, bacteria can act as "mycorrhizae helpers." Some endophytic PGPR that release cellulose and pectinase (Yu et al., 2011) can also facilitate the penetration of the root by fungal hyphae. This observation was also found in our experiment due to the presence of different bacterial strains with marked qualities of PGPR. A small plant root section $(1 \mathrm{~cm})$ can be colonized by many fungal species with different mutual benefits. The occurrence of the mycorrhizo-rhizobic associations is very evident in the root apparatuses of Fabaceae used in our experiment.

Although the common paradigm is that plants are not able to uptake hydrocarbons from the soil, our findings suggested that plants themselves may play a role in taking up a fraction (even small) of TPH into their tissues, in accordance with the evidence provided by many studies (Hunt et al., 2019 and references therein). Our experiment showed that hydrocarbon translocation into the aerial part of plants is limited and fixation occurs mainly in roots (Zhang et al., 2017), mainly due to the high molecular mass and hydrophobic properties. In our experiments the mycorrhizae colonization may have promoted the accumulation of hydrocarbons in plants roots, although this pathway represented only a partial fraction of their overall removal from soil. It is noteworthy that the conformation and the structure of hydrocarbons is a factor determining the success of the experiment. In our study, the presence of heavier hydrocarbons $(C>12)$ strongly influenced the degradation rate of TPH. Indeed, in all the four subzones, the degradation chrono-sequence revealed that hydrocarbons with shorter chains $(\mathrm{C}<12)$ are better degraded than the more recalcitrant ones which may require a longer time.

\section{CONCLUSION}

The integrated biological systems used for the reduction of hydrocarbons in soils are an interesting form of technology with great prospects, which may result in improving environmental quality, protecting human health, and restoring agricultural soil functions through relatively low-cost protocols. In order for these systems to achieve positive effects on bioremediation, the right combination of different biological elements and good agronomic practice must be well-designed. First, preliminary site investigations, to acquire an understanding of all aspects involved, are fundamental for the success of the work. Moreover, the chronosequence of the various operations is necessary for the final effectiveness. Therefore, land-farming-biostimulation-phytoremediation with assisted HMF are phases of a single process which, with the progress of the work, increases its effectiveness more and more, since it is an extremely efficient system in adapting to the site conditions.

The AMF-assisted land-farming-biostimulationphytoremediation design should include (i) the right combination of nutrients and (ii) the best plant-microorganism combination, which may enhance ecotype resistance to toxic organic pollutants. Special consideration should be given to the features of the plant root system, which should meet the requirements of having (i) a rapid and maximum extension, (ii) considerable biomass renewal, (iii) susceptibility to AMF infections, and (iv) a high rate of root exudates release, which represent a source of hydrophobic petroleum compounds degrading enzymes and easily available $\mathrm{C}$.

The extension of rhizosphere capacity through the hyphae networks produced by mycorrhizae results in the development of a native hydrocarbon-degrading microbial flora and/or PGPR that participate directly or indirectly in the degradation and extraction of hydrocarbons. The monitoring activities that we propose in our biological system are very effective in understanding the synergistic and progressive mechanism that is established at the level of rhizosphere soil. These multiple and progressive biological systems allow us to address bioremediation problems which had previously been unsolvable due to the lack of knowledge. The importance of real-scale experimentation is fundamental for a correct technological transfer of the combinations adopted. This is the only way to understand the real mechanisms of symbiotic aggregation, of plant homeostatic 
response, and consequent activity of the rhizosphere complex. Our full-scale experiment has actually produced positive effects on the degradation of TPH and provided a wealth of knowledge on the dynamics of the various synergistic activities (PGPR, rhizosphere enzymes, etc.) existing in the soil environment under abiotic stress conditions. The signaling path between plants and associated microorganisms would be a promising line of research for future studies aimed at improving the rehabilitation of industrial soil and offering more sustainable management in agriculture conditions.

\section{DATA AVAILABILITY STATEMENT}

The datasets generated for this study can be found in the online repositories. The names of the repository/repositories and accession number(s) can be found below: https://www.ebi.ac.uk/ ena/submit/sra/\#home.

\section{REFERENCES}

Andrade, G., Mihara, K. L., Linderman, R. G., and Bethlenfalvay, G. J. (1997). Bacteria from rhizosphere and hyphosphere soils of different arbuscularmycorrhizal fungi. Plant Soil 192, 71-79.

Balseiro-Romero, M., Gkorezis, P., Kidd, P. S., Van Hamme, J., Weyens, N., Monterroso, C., et al. (2017). Use of plant growth promoting bacterial strains to improve Cytisus striatus and Lupinus luteus development for potential application in phytoremediation. Sci. Total Environ. 581, 676-688. doi: 10. 1016/j.scitotenv.2016.12.180

Bell, T. H., El-Din Hassan, S., Lauron-Moreau, A., Al-Otaibi, F., Hijri M., Yergeau, E., et al. (2014). Linkage between bacterial and fungal rhizosphere communities in hydrocarbon-contaminated soils is related to plant phylogeny. ISME J. 8, 331-343. doi: 10.1038/ismej.2013.149

Burges, A., Epelde, L., Blanco, F., Becerril, J. M., and Garbisu, C. (2017). Ecosystem services and plant physiological status during endophyte-assisted phytoremediation of metal contaminated soil. Sci. Total Environ. 584, 329-338. doi: 10.1016/j.scitotenv.2016.12.146

Cougnon, M., De Swaef, T., Lootens, P., Baert, J., De Frenne, P., and Shahidi, R. (2017). In situ quantification of forage grass root biomass, distribution and diameter classes under two N fertilisation rates. Plant Soil 411, 409-422. doi: 10.1007/s11104-016-3034-7

DePoy, E., and Gitlin, L. N. (eds.). (2016). "Chapter 20 - Statistical analysis for experimental-type designs," in Introduction to Research (Fifth Edition) (Mosby), 282-310. doi: 10.1016/B978-0-323-26171-5.00020-3

Devatha, C. P., Vishnu, V. A., Purna Chandra, and Rao, J. (2019). Investigation of physical and chemical characteristics on soil due to crude oil contamination and its remediation. Appl. Water Sci. 9:89.

Field, A. (2009). Discovering Statistics Using SPSS, 3rd Edn. London: Sage Publications.

Gao, Y., and Zhu, L. (2004). Plant uptake, accumulation and translocation of phenanthrene and pyrene in soils. Chemosphere 55, 1169-1178. doi: 10.1016/j. chemosphere.2004.01.037

Gaur, N., Narasimhulu, K., and PydiSetty, Y. (2018). Recent advances in the bio-remediation of persistent organic pollutants and its effect on environment. J. Clean. Prod. 198, 1602-1631. doi: 10.1016/j.jclepro.2018. 07.076

Gianfreda, L. (2015). Enzymes of importance to rhizosphere processes. J. Soil Sci. Plant Nutr. 15, 283-306.

Gkorezis, P., Daghio, M., Franzetti, A., Van Hamme, J. D., Sillen, W., and Vangronsveld, J. (2016). The interaction between plants and bacteria in the remediation of petroleum hydrocarbons: an environmental perspective. Front. Microbiol. 7:1836.

\section{AUTHOR CONTRIBUTIONS}

DZ, CG, MT, and RS contributed to conception and design of the study. RS organized the database. DZ analyzed the data and wrote the original draft of the manuscript. CG supervised. All authors contributed to manuscript critical evaluation, revision, read, and approved the submitted version.

\section{FUNDING}

This research was funded by Italian MIUR PRIN2017BHH84R.

\section{SUPPLEMENTARY MATERIAL}

The Supplementary Material for this article can be found online at: https://www.frontiersin.org/articles/10.3389/fmicb. 2020.621581/full\#supplementary-material

Greer, C. W., Whyte, L. G., and Niederberger, T. D. (2010). "Microbial communities in hydrocarbon contaminated temperate, tropical alpine, and polar soils," in Handbook of Hydrocarbon and Lipid Microbiology, ed. K. N. Timmis (Berlin: Springer-Verlag), 2313-2328.

Grifoni, M., Rosellini, I., Angelini, P., Petruzzelli, G., and Pezzarossa, B. (2020). The effect of residual hydrocarbons in soil following oil spillages on the growth of Zea mays plants. Environ. Pollut. 265:114950. doi: 10.1016/j.envpol.2020. 114950

Gu, Y., Wang, P., and Kong, C. H. (2009). Urease, invertase, dehydrogenase and polyphenoloxidase activities in paddy soil influenced by allelopathic rice variety. Eur. J. Soil Biol. 45, 436-441. doi: 10.1016/j.ejsobi.2009.06.003

Guarino, C., and Sciarrillo, R. (2017). Effectiveness of in situ application of an integrated phytoremediation system (IPS) by adding a selected blend of rhizosphere microbes to heavily multi-contaminated soils. Ecol. Eng. 99, 70-82.

Guarino, C., Marziano, M., Tartaglia, M., Prigioniero, A., Postiglione, A., Scarano, P., et al. (2020). Poaceae with PGPR bacteria and arbuscular mycorrhizae partnerships as a model system for plant microbiome manipulation for phytoremediation of petroleum hydrocarbons contaminated agricultural soils. Agronomy 10:547. doi: 10.3390/agronomy10040547

Guarino, C., Spada, V., and Sciarrillo, R. (2017). Assessment of three approaches of bioremediation (natural attenuation, landfarming and bioagumentation assistited landfarming) for a petroleum hydrocarbons contaminated soil. Chemosphere 170, 10-16. doi: 10.1016/j.chemosphere.2016.11.165

Guarino, C., Paura, B., and Sciarrillo, R. (2018). Enhancing phytoextraction of HMs at real scale, by combining salicaceae trees with microbial consortia. Front. Environ. Sci. 6:137. doi: 10.3389/fenvs.2018.00137

Guarino, C., Zuzolo, D., Marziano, M., Conte, B., Baiamonte, G., Morra, L., et al. (2019). Investigation and assessment for an effective approach to the reclamation of polycyclic aromatic hydrocarbon (PAHs) contaminated site: SIN Bagnoli. Italy. Sci. Rep. 9:11522.

Guyonnet, J. P., Guillemet, M., Dubost, A., Simon, L., Ortet, P., Barakat, M., et al. (2018). Plant nutrient resource use strategies shape active rhizosphere microbiota through root exudation. Front. Plant Sci. 9:1662.

Hall, J., Soole, K., and Bentham, R. (2011). Hydrocarbon phytoremediation in the family Fabacea - a review. Int. J. Phytoremediation 13, 317-332. doi: $10.1080 / 15226514.2010 .495143$

Hayat, S., Hayat, Q., Alyemeni, M. N., Wani, A. S., Pichtel, J., and Ahmad, A. (2012). Role of proline under changing environments: a review. Plant Signal. Behav. 7, 1456-1466. doi: 10.4161/psb.21949

Hernández-Ortega, H. A., Alarcón, A., Ferrera-Cerrato, R., Zavaleta-Mancera, H. A., López-Delgado, H. A., and Mendoza-López, M. R. (2012). Arbuscular mycorrhizal fungi on growth, nutrient status, and total antioxidant activity of 
Melilotus albus during phytoremediation of a diesel-contaminated substrate. J. Environ. Manage. 95, S319-S324.

Hoang, S. A., Lamb, D., Seshadri, B., Sarkar, B., Choppala, G., Kirkham, M. B. et al. (2021). Rhizoremediation as a green technology for the remediation of petroleum hydrocarbon-contaminated soils. J. Hazard. Mater. 401:123282. doi: 10.1016/j.jhazmat.2020.123282

Hunt, L. J., Duca, D., Dan, T., and Knopper, L. D. (2019). Petroleum hydrocarbon (PHC) uptake in plants: a literature review. Environ. Pollut. 245, 472-484. doi: 10.1016/j.envpol.2018.11.012

Hussain, I., Puschenreiter, M., Gerhard, S., Sani, S. G. A. S., Khan, W., Khan, U. D., et al. (2019). Differentiation between physical and chemical effects of oil presence in freshly spiked soil during rhizoremediation trial. Environ. Sci. Pollut. Res. 26, 18451-18464. doi: 10.1007/s11356-019-04819-6

Hussain, I., Puschenreiter, M., Gerhard, S., Schöftner, P., Yousaf, S., Wang, A., et al. (2018). Rhizoremediation of petroleum hydrocarbon-contaminated soils: improvement opportunities and field applications. Environ. Exp. Bot. 147, 202-219. doi: 10.1016/j.envexpbot.2017.12.016

Johannsson, J. F., Paul, L. R., and Finlay, R. D. (2004). Microbial interactions in the mycorrhizosphere and their significance for sustainable agriculture. FEMS Microbiol. Ecol. 48, 1-13. doi: 10.1016/j.femsec.2003.11.012

Kaczyñska, G., Borowik, A., and Wyszkowska, J. (2015). Soil dehydrogenases as an indicator of contamination of the environment with petroleum products. Water Air Soil Pollut. 226:372. doi: 10.1007/s11270-015-2642-9

Khudur, L. S., Shahsavari, E., Webster, G. T., Nugegoda, D., and Ball, A. S. (2019). The impact of lead co-contamination on ecotoxicity and the bacterial community during the bioremediation of total petroleum hydrocarboncontaminated soils. Environ. Pollut. 253, 939-948. doi: 10.1016/j.envpol.2019. 07.107

Kiamarsi, Z., Kafi, M., Soleimani, M., Nezami, A., and Lutts, S. (2020). Conjunction of Vetiveria zizanioides L. and oil-degrading bacteria as a promising technique for remediation of crude oil-contaminated soils. J. Clean. Prod. 253:119719. doi: 10.1016/j.jclepro.2019.119719

Koshlaf, E. S., and Ball, A. (2017). Soil bioremediation approaches for petroleum hydrocarbon polluted environments. AIMS Microbiol. 3, 25-49. doi: 10.3934/ microbiol.2017.1.25

Labbé, J., Jorge, V., Kohler, A., Vion, P., Marçais, B., Bastien, C., et al. (2011). Identification of quantitative trait loci affecting ectomycorrhizal symbiosis in an interspecific F1 poplar cross and differential expression of genes in ectomycorrhizas of the two parents: Populus deltoides and Populus trichocarpa. Tree Genet. Genomes 7, 617-662. doi: 10.1007/s11295-0100361-3

Legislative Decree 152/2006 (2006). DECRETO LEGISLATIVO 3 aprile 2006, n. 152 "Norme in materia ambientale," Gazzetta Ufficiale n. 88 14-4-2006, Suppl Ord n. 96. Available online at: http://www.camera.it/parlam/leggi/deleghe/ 06152dl.htm

Liu, R., Dai, Y., and Sun, L. (2015). Effect of rhizosphere enzymes on phytoremediation in PAH-contaminated soil using five plant species. PLoS One 10:e0120369. doi: 10.1371/journal.pone.0120369

Ossai, I. C., Ahmed, A., Hassan, A., and Hamid, F. S. (2020). Remediation of soil and water contaminated with petroleum hydrocarbon: a review. Environ. Technol. Innov. 17:100526. doi: 10.1016/j.eti.2019.100526

Palmroth, M. R. T., Koskinen, P. E. P., Pichtel, J., Vaajasaari, K., Joutti, A., Tuhkanen, T. A., et al. (2006). Field-scale assessment of phytotreatment of soil contaminated with weathered hydrocarbons and heavy metals. J. Soils Sediments 6, 128-136. doi: 10.1065/jss2006.07.170

Pawlik, M., Cania, B., Thijs, S., Vangronsveld, J., and Piotrowska-Seget, Z. (2017). Hydrocarbon degradation potential and plant growth-promoting activity of culturable endophytic bacteria of Lotus corniculatus and Oenothera biennis from a long-term polluted site. Environ. Sci. Pollut. Res. 24, 19640-19652. doi: 10.1007/s11356-017-9496-1

Poole, E. J., Bending, G. D., Whipps, J. M., and Read, D. J. (2001). Bacteria associated with Pinus sylvestris-Lactarius rufus ectomycorrhizas and their effects on mycorrhiza formation in vitro. New Phytol. 151, 743-751. doi: 10. 1046/j.0028-646x.2001.00219.x
Rajtor, M., and Piotrowska-Seget, Z. (2016). Prospects for arbuscular mycorrhizal fungi (AMF) to assist in phytoremediation of soil hydrocarbon contaminants. Chemosphere 162, 105-116. doi: 10.1016/j.chemosphere.2016.07.071

Rusin, M., Gospodarek, J., Barczyk, G., and Nadgórska-Socha, A. (2018). Antioxidant responses of Triticum aestivum plants to petroleum-derived substances. Ecotoxicology 27, 1353-1367. doi: 10.1007/s10646-018-1988-3

Serrano, A., Gallego, M., González, J. L., and Tejada, M. (2008). Natural attenuation of diesel aliphatic hydrocarbons in contaminated agricultural soil. Environ. Pollut. 151, 494-502. doi: 10.1016/j.envpol.2007.04.015

Shukry, W. M., Al-Hawas, G. H. S., Al-Moaikal, R. M. S., and El-Bendary, M. A. (2013). Effect of petroleum crude oil on mineral nutrient elements, soil properties and bacterial biomass of the Rhizosphere of Jojoba. Br. J. Environ. Clim. Change 3, 103-118. doi: 10.9734/bjecc/2013/2492

Siles, J. A., and Margesin, R. (2018). Insights into microbial communities mediating the bioremediation of hydrocarbon-contaminated soil from an Alpine former military site. Appl. Microbiol. Biotechnol. 102, 4409-4421. doi: 10.1007/s00253018-8932-6

Thijs, S., Sillen, W., Rineau, F., Weyens, N., and Vangronsveld, J. (2016). Towards an Enhanced understanding of plant-microbiome interactions to improve phytoremediation: engineering the metaorganism. Front. Microbiol. 7:341.

United States Environmental Protection Agency [USEPA] (2017). "Landfarming Chapter V," in How to Evaluate Alternative Cleanup Technologies for Underground Storage Tank Sites. A Guide for Corrective Action Plan Reviewers, Land And Emergency Management 5401R (Washington, DC: EPA).

Vaajasaari, K., and Joutti, A. (2006). Field-scale assessment of phytotreatment of soil contaminated with weathered hydrocarbons and heavy metals (9 pp). J. Soils Sediments 6, 128-136. doi: 10.1065/jss2006.07.170

Vestergaard, G., Schulz, S., Schöler, A., and Schloter, M. (2017). Making big data smart-how to use metagenomics to understand soil quality. Biol. Fertil. Soils 53, 479-484. doi: 10.1007/s00374-017-1191-3

Vidonish, J. E., Zygourakis, K., Masiello, C. A., Sabadell, G., and Alvarez, P. J. J. (2016). Thermal treatment of hydrocarbon-impacted soils: a review of technology innovation for sustainable remediation. Engineering 2, 426-437. doi: 10.1016/j.eng.2016.04.005

Vohník, M., Páne, M., Fehrer, J., and Selosse, M. (2016). Experimental evidence of ericoid mycorrhizal potential within Serendipitaceae (Sebacinales). Mycorrhiza 26, 831-846. doi: 10.1007/s00572-016-0717-0

Wang, B., Xie, H. L., Ren, H. Y., Li, X., Chen, L., and Wu, B. C. (2019). Application of AHP,TOPSIS, and TFNs to plant selection for phytoremediation of petroleum-contaminated soils in shale gas and oilfields. J. Clean. Prod. 233, 13-22. doi: 10.1016/j.jclepro.2019.05.301

Woliñska, A., Kuźniar, A., Szafranek-Nakonieczna, A., Jastrzêbska, N., Roguska, E., and Stêpniewska, Z. (2016). Biological activity of autochthonic bacterial community in oil-contaminated soil. Water Air Soil Pollut. 227:130.

Yu, X. Z., Wu, S. C., Wu, F. Y., and Wong, M. H. (2011). Enhanced dissipation of PAHs from soil using mycorrhizal ryegrass and PAH-degrading bacteria. J. Hazard. Mater. 186, 1206-1217. doi: 10.1016/j.jhazmat.2010. 11.116

Zhang, C., Feng, Y., Liu, Y. W., Chang, H. Q., Li, Z. J., and Xue, J. M. (2017). Uptake and translocation of organic pollutants in plants: a review. J. Integr. Agric. 16, 1659-1668. doi: 10.1016/s2095-3119(16)61590-3

Conflict of Interest: The authors declare that the research was conducted in the absence of any commercial or financial relationships that could be construed as a potential conflict of interest.

Copyright (c) 2021 Zuzolo, Guarino, Tartaglia and Sciarrillo. This is an open-access article distributed under the terms of the Creative Commons Attribution License (CC BY). The use, distribution or reproduction in other forums is permitted, provided the original author(s) and the copyright owner(s) are credited and that the original publication in this journal is cited, in accordance with accepted academic practice. No use, distribution or reproduction is permitted which does not comply with these terms. 